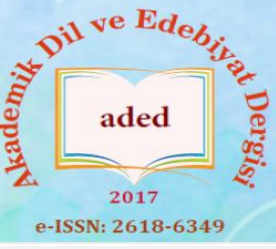

Akademik Dil ve Edebiyat Dergisi

Academic Journal of Language and Literature

Cilt/Volume: 3, Sayı/Issue: 4, (Aralık/December 2019)

USTALARA SAYGI-I:

Prof. Dr. Fatma Sabiha KUTLAR OĞUZ'a Armağan

\title{
Takriz Bir Tür Müdür?
}

\author{
Is Takriz a Genre?
}

\section{Nagihan GÜR*}

${ }^{\star}$ Dr. Öğr. Üyesi, Ankara Sosyal Bilimler Üniversitesi

e-mail*: nagihan.gur@asbu.edu.tr

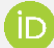

https://orcid.org/0000-0001-6540-1102

Araştırma Makalesi/Research Article

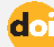

https://doi.org/10.34083/akaded.647746

Sorumlu Yazar/Corresponding Author Nagihan Gür, Ankara Sosyal Bilimler Üniversitesi, Ankara/Türkiye

Geliș Tarihi/Received : 17.11.2019

Kabul Tarihi/Accepted: 04.12.2019

\section{Atıf/Citation}

GÜR, Nagihan (2019). Takriz Bir Tür Müdür?, Akademik Dil ve Edebiyat Dergisi, 3 (4), 390-408.

DOI: 10.34083 /akaded.647746

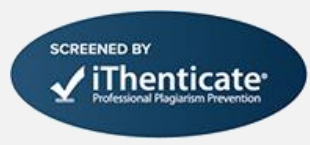

\section{Öz}

En genel tanımıyla eserler ve yazarlar hakkında yazılmış övücü nitelikte tanıtım yazıları olarak tanımlanan takrizler, Osmanlı edebiyatının hemen her döneminde üretim alanı bulmuş, farklı şekil ve içerikleriyle kendine özgü bir gelenek oluşturmuştur. Sanat ortamında tutunmaya çalışan şairlerin/yazarların otorite saydıkları kişilerden takriz ricasında bulunması, takdir görme ve geleneğe eklemlenme çabalarının bir yansımasıdır. Takriz yazarak başkalarının eserlerini tanıtan/takdim eden kişiler için ise bu yazın pratiği, kendi sanat güçlerini sınadıkları ve geleneğin ideal sanat anlayışını yerleştirmeye çalıştıkları bir söylem alanı oluşturur. Takrizlerin pek çok farklı türde yazılmış eserde karşımıza çıkması, bu metinlerin Osmanlı edebiyatındaki yaygınlığına işaret etmektedir. Bâkî, Nevî̀, Nâbî, Şeyh Gâlib, Nedîm, Seyyid Vehbî ve Koca Râgıb Paşa gibi Osmanlı edebiyatının önemli temsilcilerinin başkalarının eserlerine takriz yazması ve bazılarının yazmış oldukları takrizlere kendi divanlarında yer vermesi, bu metinlere belirli bir yazınsal değer atfedildiğini göstermektedir. Osmanlı dönemi takriz metinlerini merkeze alacağım bu makalede, takrizlerin bir tür olup olmadığını tartışmaya açacağım. Bu bağlamda, ilk olarak takrizlerin biyografik eserlerde, divan ve mecmualardaki temsilleri üzerinde duracağım. Takrizlerin şekilsel ve üslupsal özelliklerini bazı takriz örnekleri üzerinden tartışmaya açarak bu geleneğin yazınsal değerini ve türsel özelliklerini ortaya koymaya çalışacağım.

Anahtar Kelimeler: Takriz, Osmanlı edebiyatı, gelenek, edebî türler, edebî tür tasnifleri.

*Bu makale, tarafımca hazırlanan "Klâsik Türk Edebiyatında Takriz Geleneği” (2014) başlıklı basılmamış doktora tezinden özgünleştirilerek yeniden üretilmiştir. 


\section{Is Takriz a Genre?}

\section{Abstract}

Takriz, which is defined as introductory articles written in order to praise the works and writers, found a field of production in almost every period of the Ottoman literature and formed a unique tradition with its different forms and contents. Poets or writers who wanted to find a place in literary and artistic circles asked for takriz from the people whom they considered as authority. This was a reflection of their efforts to be appreciated and to be articulated in the tradition. For those who introduce and promote the works of others, writing a takriz was an area of discourse where they tested their own artistic power and tried to consolidate the ideal conception of the literary tradition. The fact that the takriz appeared in many different genres points to the prevalence of this writing in Ottoman literature. The important representatives of Ottoman literature such as Bâkî, Nevî̀, Nâbî, Şeyh Gâlib, Nedîm, Seyyid Vehbî and Koca Râgıb Pasha wrote takriz for the works of others and some of them included these takriz in their own divans. This shows that takriz was given a certain literary value. In this article, I will focus on the takriz-writing in the Ottoman literature, and I will discuss whether the taqriz can be considered as a genre. In this context, I will first focus on its representations in the biographical dictionaries, divans and mecmîas. Then, I will try to reveal the literary value and the characteristic of this tradition by discussing the formal and stylistic features of the takriz through some examples.

Key Words: Takriz, Ottoman literature, tradition, literary genre, literary genre classifications. 
Osmanlı edebiyatında farklı yüzyıllarda üretilmiş ve çeşitli eserlere yazılmış manzum ve mensur birçok takriz örneğine rastlanır. ${ }^{1}$ Divan, mesnevi, mecmûa, tezkire, sözlük, sakînâme, sûrnâme, nasihatnâme, menâkıbnâme, kıssa, belâgat kitapları, tarihler, şerh metinleri ve fikıh kitapları gibi çok farklı eserde karşımıza çıkan takriz örnekleri, ${ }^{2}$ bu metinlerin Osmanlı edebiyatında yerleşmiş bir geleneği olduğunu ortaya koymaktadır. En genel tanımıyla eserler ve yazarlar hakkında yazılmış övücü nitelikte tanıtım yazıları olarak tanımlanan ve yazıldıkları eserlerin başına ya da sonuna konulan takrizler ${ }^{3}$, Osmanlı klasik sanat anlayışının temsil bulduğu yazın pratiklerinden biridir. Sanat ortamında tutunmaya çalışan şairlerin/yazarların otorite saydıkları kişilerden takriz ricasında bulunması, takdir görme ve geleneğe eklemlenme çabasının bir yansımasıdır. Takriz yazarak başkalarının eserlerini tanıtan/takdim eden kişiler için ise bu pratik, kendi sanat güçlerini sınadıkları ve geleneğin ideal sanat anlayışını yerleştirmeye çalıştıkları bir söylem alanı yaratır. Peki, Osmanlı edebiyatında yaygın ve yerleşmiş bir geleneği olan takrizleri bir yazın türü olarak değerlendirmek mümkün müdür? Bu soruya, takrizlerin şekilsel ve üslupsal özellikleri ve birincil kaynaklardaki temsilleri üzerinden birtakım cevaplar sunmaya çalışacağım.

\footnotetext{
${ }^{1}$ Takrizler, Arap ve Fars edebiyatlarında da görülmektedir. Takrizlerin Türk edebiyatındaki ilk örnekleri 12. yüzyıla uzanmaktadır. Türk edebiyatın ilk dönem edebi metinleri olan Kutadgu Bilig ve Atabetü'l Hakâyık'a sonradan eklenen manzummensur önsözler, içerdiği övücü söylem, yazar ve esere ilişkin nitelendirmeleriyle takriz olarak değerlendirilmiştir. Bu konudaki değerlendirmeler için bkz: Yavuz 2009: 167, Arat 2007: XXX, Arat 2006: 127, Gür 2014 ve 2017. Takrizler, modernleşme dönemi Türk edebiyatı ve sonrasında da üretilmeye devam etmiştir.

Takriz geleneğini farklı perspektiflerden yorumlayan modern çalışmalar için bkz: Karataş, 2002; Vesely 2003; Rosenthal 1981; Woodhead 2000; Uzun-Arslan 2010; Levanoni 2013; Gür 2012, 2014, 2016, 2017; Bauer 2014; Burak 2015; Elçi 2016, Averbek 2019.

${ }^{2}$ Hangi türde eserlere takriz yazıldığını ortaya koyan detaylı bir tablo için bkz: Gür, “Takrizler Hangi Eserlere Yazilır?” 2014: 74-77.

3 "Medh etmek, edilmek" anlamını içeren takriz kelimesi, telif eserler hakkında kullanılan bir tâbirdir. "Bir telife medih yollu yazllan mensur veya manzum makale" (Lügat-i Nâci 2009: 658) yâhut, "bir telifi mensur veya manzum bir makale-i mahsûse ile medh ü sena etme" (Kâmûs-i Türkî 1317: 426) şeklinde tanımlanan takriz, birçok sözlük ve ansiklopedi maddesinde benzer şekilde tanımlanmıştır. Takrizler, sitayiş, tarih, mektup, takdim, iltifât, iltifatnâme, medih, mukaddime, dibâce, tarih, imza, tebrik ve teşekkür gibi farklı adlandırmalarla da karşımıza çıkmaktadır.
} 


\section{Biyografi Yazınında Takrizlerin İzlerini Sürmek}

Râmiz, Âdâb-ı Zürefầnın "Kâmî" maddesinde şairin eserlerini tanıtırken şöyle bir ifadeye yer vermiştir: "Âsârlarından Fetevâ-yı Kâ'idiyye ta likâtı ve ba'zı resầil ü takrîzâtı ve müretteb Divân-ı pür-nikâtı vardır. Cümlesi makbûl-i cümle-i enâm ve müntesib-i tarîkat-i 'aliyye bir mîr-i hucestehırâm idi" (Erdem 1994: 257). Burada Râmiz'in "ba'z1 resâ’il ü takrîzâtı” diyerek Kâmî̀nin başkarına yazmış olduğu takrizleri diğer eserleri arasında sıralaması dikkate değerdir.

Tezkiresinin "Birrî" maddesinde Sâlim, şairin Bülbüliyye mesnevisini değerlendirirken "Şu'arâdan katı çok kimesneler bu te'lif-i hoş-âyendesine takrîz eyleyip tahsîn ve her varak-1 gül-tabak-ı nüsha-i ra'nâsın mücedvel-i zerrîn-cedvel-i ahsen ü âferîn eylemişlerdir.” ifadelerine yer vermiştir. Bu ifadelerin ardından Sâlim, Fevzînnin Bülbüliyye’ye yazdığı aşağıdaki takrizine yer vermiştir:

'Acâyib bûstân-ı râz-ı pür-feyz-i ledünnî kim

Ser-â-ser mîve-i kudsiyye ehl-i hâle elyâk bu

Sürûş-ı 'âlemi ma'nâ dediler Fevziyâ târîh

Kitâb-ı Bülbül-i Gülzâr-ı Vecd-i Birrî el-hak bu

(İnce 2005: 243-244)

İlginç bir şekilde Fevzînnin yazmış olduğu bu takriz, Bülbüliyye’ye kaydedilmiş diğer takrizler arasında yer almamaktadır. Fevzînin takrizinden, ancak Sâlim Tezkiresine kaydedilmiş bu birkaç beyit sayesinde haberdar olmaktayız. Bu durum, Fevzînnin söz konusu takrizini eser tertip edildikten sonra yazmış olabileceğini, ya da Birrînnin, bir sebeple, bu takrize mesnevisinde yer vermemiş olabileceğini düşündürmektedir.

Osmanlı Şairleri'nde Muallim Naci, Haşmet'i şöyle tanımlamıştır: "Meşhûr Râgıb Paşa'nın iltifâtına mazhar olanlardandır. Divanı vardır. İçinde iyi söz nâdir bulunur. Senedü'ş-Şu'arâ nâmındaki mensûr eserine Paşa manzûm takrîz yazmıştır." (1986: 308). Bu tanımda Râgıb Paşa'nın Senedü’ş-Şu'arầya yazdığı takrize işaret edilmesi dikkate değerdir. Muallim Naci, aynı eserin Râgıb Paşa maddesinde, "Arapçada olan kuvvetinin derecesini ise meselâ Münşeâtında kayıtlı bulunan Arapça takrîzler gösterir” (Muallim Naci 1986: 242) şeklinde bir değerlendirmede bulunmuştur. Burada, ilgili takrizin 
Râgıb Paşa'nın dil becerisini kanıtlayan bir örnek olarak değerlendirilmesi önemlidir. Osmanlı Şairleri'nin Avnî Bey maddesinde Muallim Naci, "Neşrolunmuş eserleri ise meşhur kasideci -İsmâilzâde Paşazâde- Hakkı Beyefendi’nin matbu Divan'ı gibi bir iki kitaba yazdığı renkli takrizlerle Ziya Paşa'nın Harâbât'ını nurlandıran bazı seçme beyitlerden ibaret gibidir." (Muallim Naci 1986: 144) şeklindeki ifadeleriyle yine takrizlere işaret etmiştir. Burada, Avnî Bey'in yazmış olduğu takrizlerin diğer eserleri arasında sıralanmış olması dikkate değerdir.

Bursalı Mehmed Tâhir'in Osmanlı Müellifleri, bu bağlamda değerlendirebileceğimiz bir diğer kaynaktır. Mehmed Tâhir, "İsmâil Belî̆ğ" maddesinde yazarın Güldeste-i Riyâzzı İrfân adlı eserini değerlendiren İsmail Hakkı Burusevî̀nin bu esere yazdığı manzum takrizinden söz etmiştir (Mehmed Tâhir 2000: 102-3-4). Aynı eserin Atâullâh Efendi maddesinde ise takrizlerin bahsi şöyle geçmektedir: "Müretteb dîvânı, takrîzât u münşeâtı [....], Kazasker Alizâde Efendi'nin risâlesine şerhi vardır. [....] Burhân-ı Kâtı'a güzel bir takrîzi vardır." (Mehmed Tâhir 2000: 377). Mehmed Tâhir, Osmanlı Müellifleri'nin Avnî Bey maddesinde de şairin Üsküdarlı Hakkı Bey’e yazdığı aşağıdaki takrize yer vermiştir:

Söz kâlbüd-i kadr-i benî âdeme cândır

Söz vâsıta-i râbıta-i 'âlemiyândır

Söz bir nefes-i sâzec-i bî̀-rengdir ammâ

Berhem-zen-i sûret-kede-i kevn ü mekândır

Yâ Rab bu ne kudret bu ne te'sîr ki bir söz

Revnak-şiken-i ma'reke-i seyf ü sinândır

(Mehmed Tâhir 2000: 331)

Takrizlerin, yazıldıkları eserlerden bağımsız olarak ayrı bir tür olarak algılandığını gösteren bir diğer örnek, Hüseyin Vassâfın Sefine- $i$ Evliyầ sında yer alan "Müstakimzâde Sâdeddin Süleyman" maddesidir. Hüseyin Vassâf eserinde Müstakimzâde'nin eserlerini belirli bir tasnife göre listelerken şairin yazdığı takrizlere de yer vermiştir. (Akkuş-Yılmaz II 2006: 97). Sefine-i Evliyầ da bulunan "Kerâmeddin Efendi" maddesi takrizlerin anıldığ1 bir diğer örnektir. Bu maddede, Kerâmeddin Efendi ile olan yakınlığından söz eden Hüseyin Vassâf, Kerâmeddin Efendi'ye yazdı̆̆ 1 
takrizin tamamını tezkiresine kaydetmiştir (Akkuş-Yılmaz IV 2006: 81). Söz konusu takriz, ayrıca Hüseyin Vassâf Divani'nda da yer almaktadır (Tatçı vd 2012: 130). Yine Sefine-i Evliyầnın "İbnülemin Mahmud Kemal İnal" maddesinde de İbnülemin'in Hüseyin Vassâf ın Gülzâr-ı Aşk’ına yazdığ 1 takrize yer verilmiştir. (Akkuş-Yılmaz II 2006: 393)

Yukarıda sıraladığımız biyografik eserlerin dışında, bazı modern biyografilerde de takrizlerin müstakil bir tür olarak değerlendirildiği örnekler karşımıza çıkmaktadır. Büyük Türk Klâsikleri’nde yer alan "Nergisî" maddesinde Nergisî̀ye yazılan takrizlere şöyle değinilmiştir: "1622'de tertip ederek uzun bir mukaddime ile Şeyhülislâm Yahyâ Efendi’ye ithaf ettiği [Münşeât'ında] Kazasker Ganizâde Nâdirî ile Şerif Efendi'nin birer takrizi bulunmaktadır (1987: 346). Franz Babinger, Osmanlı Tarih Yazarları ve Eserleri adlı kitabının "Safâyı" maddesinde, "Yalnızca Tezkiretü'ş-şu'arâ adıyla anılan bu eserin başında, başta Sâlim Mehmed olmak üzere, çağdaş bilginler tarafından yazılmış olan on yedi Takriz bulunmaktadır." (Babinger 1982: 282) şeklinde bir bilgiye yer verilmiştir. Biyografi ağırlıklı bu eserlerde şairlerin/yazarların sanatları ve eserlerinden bahsedilirken başkalarına yazdıkları ya da başkalarının onlara yazdığı takrizlerden söz edilmesi, takrizlerin Osmanlı edebiyatında önemli bir yeri ve işlevi olduğunu ortaya koymaktadır.

\section{Divan ve Mecmûalarda Bir Edebî Üretim Olarak Takrizler}

Bazı takriz yazarlarının başkaları için yazmış oldukları kimi takrizleri kendi divanlarına aldıkları, ya da bu şiirlerin bir şekilde sonradan divanlarına kaydedildiği görülmektedir. Bu bağlamda, çeşitli yüzyıllardan seçilmiş bazı örnekleri içeren aşağıdaki tabloya dikkat yöneltelim: ${ }^{4}$

\footnotetext{
${ }^{4} \mathrm{Bu}$ makalede takrizlere ilişkin ortaya konulan veriler ve kullanılan tablolar tarafımca hazırlanan "Klasik Türk Edebiyatında Takriz" başlıklı doktora tezinden alıntılanmıştır.
} 


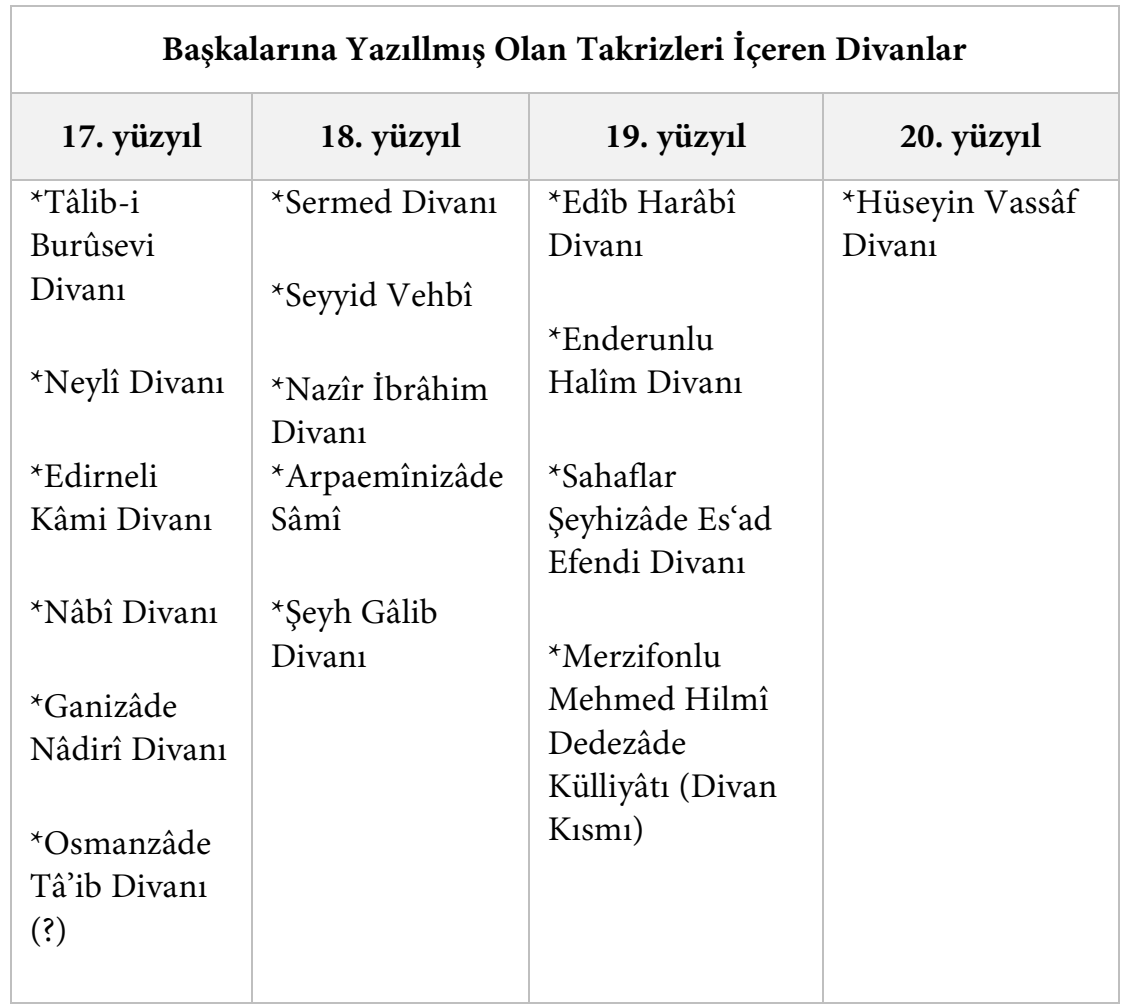

İlgili takrizlerin Neylì Divanı'nda sonda, Nazîr İbrâhim Divanı'nda kasideler arasında, Şeyh Gâlib Divânı'nda kaside ve gazel tertibinde, Hüseyin Vassâf, Edîb Harâbî ve Enderunlu Halîm divanlarında gazeller arasında, Edirneli Kâmî divanında mesnevi ve gazel tertibinde, Seyyid Vehbî, Arpaemînizâde Sâmî ${ }^{5}$ ve Sermed divanlarında mesneviler arasında, Sahaflar Şeyhizâde Es'ad Efendi Divaninda "Takrîzât" şeklinde müstakil bir başlıkta, Nâbî Divani'nda rubâi, kaside ve mesneviler arasında, Tâlib-i Burûsevî

\footnotetext{
${ }^{5}$ Arpaemînizâde Sâmî Divanı'nın iki nüshasının sonunda (Süleymaniye KütüphanesiYahya Tevfik Efendi, nu. 300 ve Bursa İnebey Yazma Eser Kütüphanesi-Ulucami, nu. 6075) mensur bir metin bulunmaktadır. Bu metin, Yahya Tevfik Efendi nüshasında “Takriz” başlı̆̆ıyla kaydedilmiştir. Söz konusu mensur metin, hazırladığım doktora tezinde takrizler arasında sıralanmıştır. Ancak daha sonra yaptığımı bir araştırmada bu metnin bir takriz olmadığı, mensur bir hezel olduğunu tespit ettim. Bu metni, edebî ve sosyal ağlar ve Sebk-i Hindî'nin mensur metinlerdeki temsili bağlamında inceleyen güncel bir çalışma için bkz: Gür 2018.
} 
Divani'nda rubâi tertibinde, Ganizâde Nâdirî Divani'nda kıt'alar arasında, Mehmed Hilmî Dedezâde'nin Külliyât'ının Divan kısmında "Medâyih" başlı̆̆ı altında ve Osmanzâde Tâ'ib'in derlenen şiirleri arasında sıralanmıştır (Gür 2014: 70) ${ }^{6}$. Bu örnekler takrizlerin gazel, kaside, mesnevi ve diğer nazım şekilleriyle yazılan her türden şiirle boy ölçüssebilecek değerde görüldügünü ortaya koymaktadır. Öyle ki Nâbî, Şeyh Gâlib, Seyyid Vehbî, Kâmî, Arpaemînizâde Sâmî ve Osmanzâde Tâ’ib gibi şairlerin, yazdıkları takrizleri divanlarına almaya değer görmeleri, ya da bu metinlerin kendi divanlarına kaydedilmiş olması takriz metinlerinin yalnızca ilişkili oldukları esere konulmak için kaleme alınmadıklarını göstermektedir.

Bazı takriz örnekleri, yazıldığı eserle hiç ilişkilendirilmeden doğrudan takriz yazarlarının edebî üretimlerine dâhil olmuştur. Yukarıda değindiğimiz Fevzînnin takrizi buna örnektir. Benzer şekilde, Hüseyin Vassâf Divaninnda, "Urefâ-yı Şa'baniye'den Merhûm Cabbârzâde 'Ârif Begin Hazret-i Sünbül'ün Nutk-1 Şerîfine Yazdığı Şerhe Takrîz Makâmında Söylenmiştir” başlğ̆ıyla yer alan takrizin, Cabbarzâde Ârif Beg'in müellif hattı olan Sünbül Sinan Şerhi'nde yer almadığı görülmektedir. Bu durum, Fevzînnin ve Hüseyin Vassâfın yazmış oldukları takrizleri söz konusu eserler tamamlandıktan sonra yazmış olabileceklerini, ya da Birrînnin ve Cabbarzâde'nin kendilerine yazılan bu takrizleri bir sebeple eserlerine koymamış olabileceklerini düşündürmektedir. Bu takrizlerin yazıldıkları eserlerden bağımsız olarak ilgili tezkire ve divana kaydedilmiş olması, takrizlerin yazıldıkları eserlerden bağımsız olarak dolaşımda olduğuna işaret etmektedir.

Divanlar dışında bazı mecmûalarda da takriz örneklerine rastlamak mümkündür. Süleymaniye Kütüphanesi'nde bulunan Aşir Efendi No: 417 ve Şehid Ali Paşa No: 2831 künyeli mecmûalarda, "Takrizât" ve "Takrîz ve Mekâtib" başlıklarıyla kaydedilmiş mensur takrizler yer almaktadır. ${ }^{7} \mathrm{Bu}$

6 Takriz yazarlarının eserlerine aldıkları takrizlerin bazen yazıldıkları eserlerdeki içeriklerinden farklı oldukları görülür. Seyyid Vehbî ve Arpaeminizâde Sâmî, Vahîd Mahtûmî Divanı'na yazdıkları takrizleri kendi divanlarınlarına alırken -ya da bu şiirler daha sonra divan nüshalarına kaydedilirken- beyitlerin sıralamasını değiştirmişler ve bazı beyitlere yer vermemişlerdir.

${ }^{7}$ Süleymaniye Kütüphanesi Aşir Efendi No: 417 künyeli yazmada bulunan takrizlerin başlıkları şu şekildedir: Takrîz-i Şeyhülislâm Es'âd Efendi (v. 190a); İmzâ-1 el-Musûlî Yahyâ Efendi ibn Seyhülislâm Zekeriyyâ Efendi el-merhûm (v. 190b); İmzâ-1 Sadrü’lulemâ Abdül'azîz Efendi ibn el-Musûlî Sa'deddin mu'allimü’s-sultân (v. 190b-191b); Takrîz-i Şerîf Efendi (v. 191b); Takrîz-i Hüseyin Efendi (v. 191b-192a); Takrîz-i 
mensur takriz örnekleri, takrizlerin inşa geleneğinde belirli bir yeri olduğunu ve -tıpkı mektup vb. mensur türler gibi- münşeat mecmûlarında örnek bir tür olarak konumlandırıldıklarını göstermektedir. Buraya kadar işaret ettiğimiz tüm bu örnekler takrizlerin Osmanlı edebiyat geleneğinde yazınsal bir tür olarak değer gördüğünü açıkça ortaya koymaktadır.

\section{Takrizlerin Türsel ve İçeriksel Özellikleri}

İncelediğimiz manzum takriz örneklerinde -yazılmış olduğu eserlerde yan yana sıralanan takrizler de buna dâhil- tercih edilen/yaygınlaşmış tektip bir nazım şeklinden söz etmek mümkün değildir ${ }^{8}$. Takrizlerin hangi nazım şekillerinde yazıldığını gösteren aşağıdaki tablo bu durumu örneklemektedir:

\section{Takrizlerin Nazım Şekillerine Göre Dağılımı}

\begin{tabular}{|l|l|l|l|l|l|}
\hline Mesnevi & Kit'a & Nazm & Gazel & Kaside & Rubâî \\
\hline$\% 25$ & $\% 20$ & $\% 10$ & $\% 4$ & $\% 4$ & $\% 2$ \\
\hline
\end{tabular}

Bu tabloda görüldügü üzere, takriz örneklerinin büyük bir kısmı mesnevi nazım şekliyle yazılmıştır. Bunun, elbette söz konusu nazım şeklinin takriz yazarına sunduğu ifade imkânlarıyla önemli bir ilişkisi vardır. Kıt’a nazım şeklinin, kaside ve gazel formlarına tercih edilmesi ve neredeyse mesnevi kadar yaygın olması dikkate değer bir husustur. Nazm formunda yazılmış takrizlerin, yine kaside ve gazel formunda yazılmış örneklere kıyasla daha

Nakîbü’l-eşrâf Şeyhî Efendi (v. 192a-194a); Takrîz-i Mevcî (v. 194a-196b); Takrîz-i 'Atâkî (v. 196b-199b); Şârih-i Mesnevî Yegâne-i zamâne Sarı 'Abdullah Efendi Merhûmun Te'lîf İtdügi Nasihâtü'l-mülûk Kitabına Merhûm Bahâyî Efendinin Eyledügi Takrîzdür (v. 199b-200a); Muslihiddin Efendinin Müellif-i Eşbâh-1 Nezâyire Takrizidür (v. 200a-200b).

Süleymaniye Kütüphanesi Şehid Ali Paşa, No: 2831 künyeli yazmada mektupların içinde bulunan takrizin başlı̆̆ı ise şöyledir: Şirvân Defterdârı İken Kızılbaş Olan Nagzi Beg Kaside-i Masnu'a-i Selmâna İtdügi tatabbu'a Bu Fakîrün 'İcâleten Yazdugı Takrîzi Perişân-edâdur (v. 60b-61a).

${ }^{8} \mathrm{Bu}$ makalede takrizlerin türsel özelliklerine ilişkin ileri sürdügüm genel çıkarımlar, tarafımca hazırlanan "Klasik Türk Edebiyatında Takriz" başlıklı doktora tezi kapsamında, 16. ve 20. yüzyıllar arasında inceleme firsatı bulduğum 200'ye yakın takriz örneğine dayanmaktadır. 
yaygın olduğu görülmektedir. Bunların yanı sıra, bu gelenekte mensur ya da manzum-mensur olarak kaleme alınmış takriz örneklerine de rastlanmak mümkündür. Takrizlerin manzum ya da mensur olarak yazılmasını belirleyen en önemli etkenlerden biri, şüphesiz, ilişkili oldukları eserlerin şekilsel ve türsel özellikleridir. Zira birçok takriz metni -elbette bazı istisnalar dışında- içerik, üslup ve şekilsel açıdan yazıldıkları eserlerle belirli bir uyum göstermektedir. Örneğin, divanlara yazılan takriz örneklerinin hemen hemen tamamı manzumdur. ${ }^{9}$ Tezkire metinlerine yazılan takrizlerin büyük bir kısmı ise mensur, ya da manzum-mensur olarak kaleme alınmıştır. Neylî, Safâŷ̂ Tezkiresi için yazdığı takrizini, tezkirenin şekilsel özelliğiyle uyumlu bir biçimde manzum-mensur olarak yazmıştır. Bu takriz, üslup açısından da tezkire söylemiyle belirli bir uyum göstermektedir. Seyyid Vehbî ve Nedîm, Safâyî Tezkiresi'ne yazdıkları takrizlerini, benzer şekilde, tezkire söylemiyle uyumlu olarak kurgulamış ve manzum-mensur bir şekilde kaleme almışlardır.

Gerek manzum gerekse mensur takrizlerde belirli bir sanat kaygısının gözetildiği ve edebi-estetik bir söylemin öncelendiği görülmektedir. Takrizleriyle lügat bilgisini ve edebi sanatlardaki hünerlerini ortaya koymaya çalışan takriz yazarları (Uzun-Arslan 2010: 472), söz sanatlarını yoğun bir şekilde kullanmışlardır. Takriz yazarları söylemlerini geleneğin hazır kalıpları içerisine yerleştirirken belirli bir özgünlük iddiası da gözetmişlerdir. Nâbî̀ ${ }^{10}$, Seyyid Vehbî̀ ${ }^{11}$ ve Şeyh Gâlib ${ }^{12}$ divanlarında yer alan aşağıdaki takriz örnekleri, içerik ve üslup açısından bu geleneğin başarılı birer örneğidir:

${ }^{9}$ Fitnat Hanım (Topkapı Sarayı, No: H 921) ve Osman Nevres (Kaya 2007) Divanlarına yazılan takrizler bu kategori dışındadır.

${ }^{10}$ Nâbî Divâni'nda bulunan takrizler için, Ali Fuat Bilkan tarafından hazırlanan Nâb̂̂ Divanı (2011) ile Millet Yazma Eser Kütüphanesi, No: AEMNZ 418 ve Süleymaniye Kütüphanesi Hamidiye, No: 1118 künyeli yazmalardan faydalanılmıştır.

${ }^{11}$ Seyyid Vehbî Divani'nda yer alan takriz için Hamit Dikmen'in "Seyyid Vehbî ve Divanının Karşılaştırmalı Metni” (1991) başlıklı doktora tezinden ve Millet Yazma Eser Kütüphanesi No: AEMNZ 497 künyeli yazmadan faydalanılmıştır.

12 Şeyh Gâlib Divani'nda bulunan takriz için, Muhsin Kalkışım tarafından hazırlanan Şeyh Gâlib Divanı (2013), Abdülkadir Gürer’in "Şeyh Gâlib Divanı” (1993) başlıklı doktora tezi ile Süleymaniye Kütüphanesi Halet Efendi, No: 658 künyeli yazmadan faydalanılmıştır. 


\section{Manzum Takriz Örnekleri}

Gılmânân-ı Enderûn-1
Hümâyundan
Hüseyin Pâşâ-zâde
Na'tî Begün Vasf-ı
Ashâb-ı Kirâm ile
Hilye-i Hâkânî
Zeyli'ne Takrîzdir

Âferîn $\mathrm{Na}^{\mathrm{c}}$ tî-i zîbendegüher

Levhâ-pîrâ-yı nevâyîn-eser

\section{Merd-i dânişver-i} pâkîze-nihâd

Tâze nakkâş-1 kumâş-1 üstâd

Şehd-cünbân-1 şekerhây-1 dehen Terbiyet-bahş-1 mevâlîd-i sühan

Cilve-fermây-1 kümeyti ma'nâ

Reh-rev-i vâdi-i şír ü inşâ

Tâze-cevlân-1 meyâdîni hayâl

Nev-şikârî-i sahârî-i makâl

Beytinün her biri bir sünbül-i ter Misrâ'un her birisi bir gevher

\section{Takrîz Berây-1 Eş‘âr-1 Vahîdâ Çelebi}

Bâreke’llâh hoşâ yegâne eser Seyr iden mislin ahvel ola meğer

Bî-bedel gülsitân-1 ma'nâdur Tevriye anda verd-i ra'nâdur

Anda her lafz-1 dilpesend îhâm Oldı gûyâ dü-magz bir bâdâm

Haşv yok cümle lafz pür-ma'nâ

Anda bîgâne sebze nâ-peydâ

\section{[....]}

Fikre beyne's-sutûr-1

safha memerr

Oldı Dîvan Yolı

me'âle meğer

Oldı âb-ı zülâl

mefhûmı

Gözedür lafz-1 tıyn i mahtûmı
Takrîz-i Mecmû'a-i

Cenâb-1 Seyyid Pertev Efendi

Hoşâ cerîde-i nev-cild-i âsumân-misâl Ki nakş-1 zer-keşi hep zühre mâh u mihr-i cemâl

Degil cerîde-i eşâar sanki cilve ider Nigâr-hâne-i Erjeng içinde bikr-i hayâl

Yâhûd ki Cedvel-i Sîmîn-i sahn-1 Sa'dâbâd Kenârı sâde-ruhân ile Sâfî mâl-â-mâl

Ya eylemiş ola bir dilrübâ-yı sîm-endâm $\mathrm{Bu}$ hacle-gehde derâguş şâhed-i âmâl

Ya Cûy-1 Şîr'de 'aks eylemiş leb-i Şîrîn Ve yâ bu levha-i sîmînde nakş-1 gonçe-i âl

Hevâ-yı seyre düşüp gülsitân-1 eş'ârı Sipihr-i ma'nîde tâvûs-1 cennet açmış bâl 


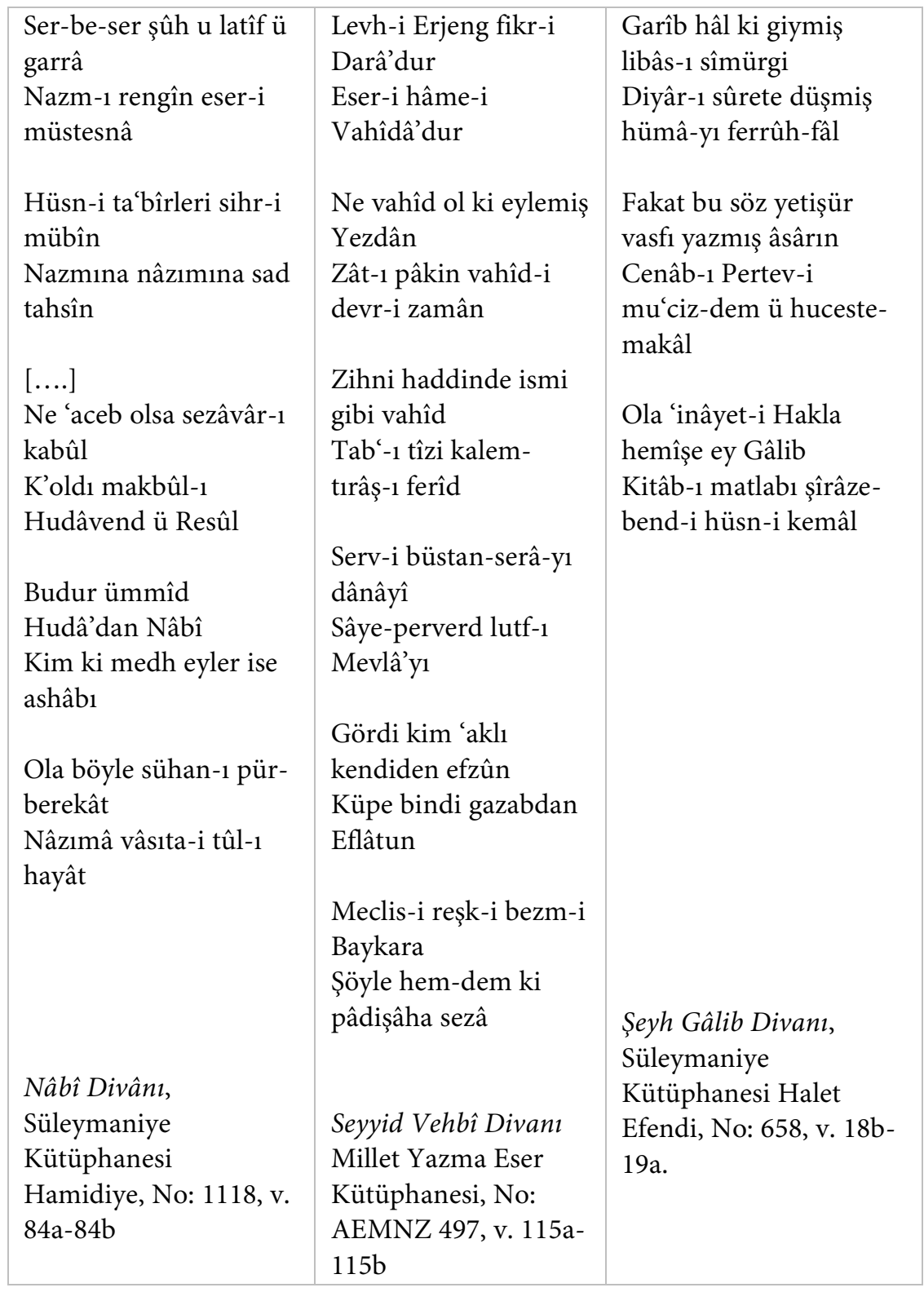

Takriz yazarlarının sanat kaygıları, mensur takriz örneklerine de yansımıştır. Seyyid Vehbî̀nin Safâyî Tezkiresìne yazdığı manzum-mensur 
takriz örneği bu bağlamda anılmaya değerdir ${ }^{13}$. Vehbî̀nin, Safâyî̀nin tezkire yazarları içerisindeki yeri ve tezkiresinin önemine vurgu yaptığı söz konusu takrizinin içeriği şöyledir:

Her safha-i müşgîn-rakamı ber-tahte şükûfezâr-1 letâyifdir ki üstâd-1 kâr her bâğbân-1 'irfânın tohm-1 süveydâsından serzede-i hadîka-i ibdâ' ve pîrâye-i ravza-i anîka-i ihtira'ı olan müntehabât-1 ezhâr-1 nâm-dâr âsârı ile müşgîn-i bahâr ve cûybâr-1 eş'âr-1 selâset-eşârr ile numûne-i المهار ختها من تجري عدن جنات eylemiş her makâlesi bir musavver meclis-i Şehnâme-i zarâyifdir ki nice Rüstem-neberd-i 'arsa-i endîşenin zûr-1 dest-i iktidârları menkabesin Mânî-i mûyîn-kalem tedkîk-i sâf-şikâf-1 musâf-1 tahkîk göstermiş mu'asker-i mürettebleşker-i evrâkında hayme-zen-i tertîb olan 'ibârât-1 sahîhatü'l-fehâvî ve suhûf-1 sutûr-1 mütesâviye-i letâyif-i metâvisi yegân yegân güzâşte-i memerr-i nazar kılındıkda her mîr-i kalem-rev-i nazmın zîr-i livâ-yı hâmesine ilticâ ve râyet-i isti'dâdına intimâ eden şirzime-i âsâr-1 tabî‘atları taklîd-i seyf ü sinân-1 hüsn-i beyân ile ârâste حق خلعت مراتهيم علي ta'bîriyle pîrâste görülüp sipeh-sâlâr-1 kitâb-1 hurûfuna gülbang-1 âferîn keşîde kılınmıştır.

(Beyazıt Devlet Kütüphanesi Veliyüddin Efendi, No: 2585, v. 6a-6b)

Nitelikli bir üst-dil ve ince hayallerle kurgulanmış bu takriz metni, başarılı bir nesir örneğidir. Seyyid Vehbî, Birrî Mehmed Dede’nin Bülbüliyye mesnevisine yazdığı, eserin içeriğiyle uyumlu olan takrizinde ${ }^{14}$ de yine nesir üslubundaki hünerini ortaya koymuştur:

El-hakk bu nüsha-i kem-yâb bir gülşen-i râzdır ki cûyibâr-1 reşehât-i hâme-i fesâhat ile sebz ü ter ve nesîm-i bahâristân1 belâgât ile letâfet-perverdir ve bu mâlike-i müşkîn-nikâb bir

${ }^{13}$ Tezkire-i Safâyî̀ deki takrizler için Pervin Çapan tarafından hazırlanan Tezkire-i Safây (2005) adlı kitap ile Millet Yazma Eser Kütüphanesi, No: Thr 771 ve Beyazıd Devlet Kütüphanesi Veliyüddin Efendi, No: 2585 künyeli yazmalardan faydalanılmıştır.

${ }^{14}$ Birrî Mehmed Dede'nin Bülbüliyye adlı eserine yazılan takrizler için Zeynep Şimşek Umaç'ın “Birrî Mehmed Dede’nin Bülbüliye Adlı Eseri Üzerine Cümle Bilgisi İncelemesi Metin-Sözlük" başlıklı yüksek lisans tezi ile Süleymaniye Kütüphanesi İzmir, No: 520 künyeli yazma ve Süleymaniye Kütüphanesi Rauf Yekta, No: 77 (1854) künyeli basma nüshadan faydalanılmıştır. 
hadîka-i nâz ü niyâzdır ki her nahlistân-1 kelimât-1 müştemilâtü'n-nikâtı âşiyân-gâh-1 belâbil-i 'irfân ve her agsân-1 şâhsâr-1 hurûf-1 zarâif-zurûfi terennüm-gâh-1 tuyûr-1 ikândır. Şükûfe-zâr-1 erkâm-1 anberîn-fâmı tarâvet-fersâ-y1 hezâr-1 gülistân ve 'uzviyet-i nev-bâve-i nukat-1 nâzüknamatı revnak-şiken-i bisyâr-1 bostândır. Sevâd-1 safâhât-1 hıyâbân-şumûli esdâf-1 bâsile-i arayis-i esrâr-1 vahdet-i vücûd ve beyâz-1 miyân-1 sutûr-1 turûs-1 mükâşefât-meşmûlü gurre ve cennât-1 şevâhid-i şühûddur.

(Süleymaniye Kütüphanesi Rauf Yekta, No: 77, v. 4b-5a)

Safâyî Tezkiresi'nde, "Müderrisîn-i Kirâmdan Nedîm Ahmed Efendi Hazretlerinin Tahrîr Eylediği Takrîzdir” başlığıyla yer alan Nedîm'e ait aşağıdaki takriz de başarılı bir manzum-mensur takriz örneğidir:

Habbezâ mecelle-i celîle-i pâkîze-edâ ki her satr-1 dil-nişîni reşk-fermâ-yı ebrû-yı dil-berâ Hitâ ve her kelime-i 'anberâgîni ser-mâye-bahş-1 tabla-1 'attâr-1 sabâdır. Riyâzî fehâvîsinde Tezkire-i Riyâzî bir gonca-i nev-demîde ve yetîme-ise âlibi bir şeb-nem-i çekîde ve reyhâne-i şihâb-1 huffâcı bir sebze-i hâbîdedir. Bir mecmû'a-1 nefîsedir ki her sahîfesinde bir nice şấir-i pakîze-edânın âsâr-1 hâmesi nümâyân ve bir mesire-i hâtır-güşâdır ki her gûşesinde bir kaç dil-berân-1 ma'nî-i bîgâne hırâmândır. Hezârân sâbâş u âferîn hâme-i hoş-edâ-yı Safâyî-i sühan-serâya ki bu gûne bir bezm-i safâya tertîb-sâz ve peymâne-i hüsn-i edâ ile ahbâb1 ser-germ ü ser-endâz eyledi.

Pâk-edâ-yı tezkire-i bî-bedel

Manzar-ı erbâb-ı dil olsa muhal

Tarhı dil-ârâ vü edâsı selîs

Tarzı pesendîde vü tavrı nefîs

Reşk Safâyî-i hüner-pervere

Verdi bu te" lîfi safâ dillere

(Beyazıt Devlet Kütüphanesi Veliyüddin Efendi, No: 2585, v. 9b) 
$\mathrm{Bu}$ örnekler, takriz metinlerinin çeşitlenmesinde takriz yazılan eserlerin şekilsel özelliklerinin, üslûplarının ve içeriklerinin ne ölçüde belirleyici olduğunu göstermektedir. Takrizlere yansıyan bu şekilsel ve üslupsal çeşitlilik, bu geleneğin daha geniş bir üretim alanı bulmasına katkı sağlamış ve böylelikle takrizleri tektipleşmiş bir yazın türü olmanın ötesine taşımıştır.

\section{Sonuç}

Edebiyat tarihlerinin satır aralarında sıkışıp kalmış olan, bazı metin neşirlerinde gözardı edilip içeriğe dahi alınmayan, yazma/yazdırılma biçimleriyle ve söylemleriyle zaman zaman olumsuzlanan takrizler, Osmanlı edebiyatında göz ardı edilemeyecek bir gelenek oluşturmuştur. $\mathrm{Bu}$ metinler, birçok farklı esere yazılmış ve usta şairlerin/nâsirlerin elinde geniş bir üretim alanı bulmuş ve edebiyat geleneğinde işlevsel bir yazın türü olarak değer görmüştür. Bu makalede takrizlerin bir tür olup olmadığını birincil kaynaklar ve seçilmiş bazı takriz örnekleri üzerinden ortaya koymaya çalıştım. Altı yüz yıllık bir edebiyat geleneğinde hemen hemen her dönemde üretilegelmiş bu metinlerin türsel özelliklerini bütünüyle ortaya koymak elbette bu makalenin sınırlarını aşan bir çalışmadır. Farklı takriz örnekleri üzerine şekilsel, içeriksel ve üslupsal okumaların ve karşılaştırmalı metin analizlerinin yapılması, şüphesiz, bu türün özelliklerini daha etraflı bir şekilde ortaya koyacaktır. Bu makalenin bu alanda yapılmış ve yapılmakta olan çalışmalara ufak da olsa bir katkı sağlamasını diliyor, takrizlerin güncel tür tasniflerinde hak ettiği yeri almasını ümit ediyorum. 


\section{Kaynakça}

Averbek, Güler Doğan (2019). "Biyografi Yazmada ve Muhitleri Belirlemede Takrizin Rolü Emirî Örneği”. dx.doi.org/10.12658/M0330.

https://www.insanvetoplum.org/online-first/biyografi-yazmadave-muhitleri-belirlemede-takrizin-rolu-emiri-ornegi. [Erişim Tarihi: 12.11.2019]

Babinger, Franz (1982). Osmanlı Tarih Yazarları ve Eserleri. Çev. Coşkun Üçok Ankara: Kültür Bakanlığı Yayınları.

Bauer, Thomas (2014). "How to create a network: Zaynaddin al-Atari". Everthing is on the Move: The Mamluk Empires as a Node in (Trans) Regional Networks. Ed. Stephan Conermann, Germany: Bonn University Press. 205-211.

Bilkan, Ali Fuat (2011). Nâbî Divanı. Ankara: Akçağ Yayınları.

Burak, Guy (2015). "Sansür, Kanonizasyon ve Osmanlı İmzâ-Takrîz Pratikleri üzerine Düşünceler”, Osmanlı Edebiyatı Çalışmaları X: Eski Metinlere Yeni Bağlamlar: Osmanlı Edebiyatı Çalışmalarında Yeni Yönelimler. İstanbul: Klasik Yayınları. 96-117.

Burak, Guy (?). "Reflections on Censorship, Canonization and the Ottoman Practices of Imza and Takriz".

https://www.academia.edu/36812819/Reflections_on_Censorship_ Canonization_and_the_Ottoman_Practices_of_Imza_and_Takriz. (Erişim Tarihi: 16. 11. 2019).

Bursalı Mehmed Tâhir (2000). Osmanlı Müellifleri I-II-III. Ankara: Bizim Büro Yayınevi.

Dikmen, Hamit (1991). Seyyid Vehbî ve Divanının Karşılaştırmalı Metni. Doktora Tezi. Ankara: Ankara Üniversitesi.

Edib Ahmed B. Ahmed Yükneki (2006). Atabetü’l-Hakâyık. Haz. Reşit Rahmeti Arat. Ankara: Atatürk Kültür, Dil ve Tarih Yüksek Kurumu Yayınları: 142.

Elçi, Fatih (2016). "Nevres-i Kadim'in Münşeât'inda Yer Alan Eleştiri İçerikli İki Takriz", Journal of Turkish Language and Literature 2, Issue: $1.139-152$.

Gür, Nagihan (2012). "Klâsik Metinlerin Nazar Duaları: Takrizler ve Yenipazarlı Vâlî̀ye Yazılan Takrizler Üzerine”. III. Uluslararası 
Türk Dili ve Edebiyatı Öğrenci Kongresi (TUDOK) Bildiriler, C. II. (Ed.) Ömür Ceylan. Istanbul: İstanbul Kültür Üniversitesi Yayınları. 1273-79.

Gür, N. (2014). Klasik Türk Edebiyatında Takriz. Doktora Tezi. Balıkesir: Balıkesir Üniversitesi Sosyal Bilimler Enstitüsü.

Gür, Nagihan. (2016). "Sanatı Sanatla İhya Etme: Osmanlı Yönetici Elit Sınıfının Elitleşme Çabası ve Takriz Yazını”. Archivum Ottomanicum, 33, 165-178.

Gür, Nagihan. (2017). "Edebiyat Tarihi Yazımında Bir Kaynak Olarak Takrizler ve Sıra Dışı İki Örnek”. Erdem Dergisi, 71-72, 91-116.

Gür, Nagihan. (2018). “Osmanlı Mizah Yazınında Bir Parodi ve Poetika Örneği: Arpaemîni-zâde Sâmî'nin Mensur Hezeli". Hicve Revâ Mizâha Mâyil: Güldürücü Metinleri Anlamak. İstanbul: Klasik Yayınları. 286-318.

Gürer, Abdülkadir (1993). Şeyh Gâlib Divanı (İnceleme-Metin). Doktora Tezi, Ankara Üniversitesi.

Hüseyin Vassâf (2012). Dîvân-Hüseyin Vassâf. Haz. Mustafa Tatçı, Metin Akkuş-İsmail Kasap. İstanbul: Kırkambar Kitaplığı.

Kalkışım, M. Muhsin (2013). Şeyh Gâlib Divanı. Ankara: Akçağ Yayınları.

Karataş, Turan (2002). Takriz Edebiyatı. Ankara: Hece Yayınları.

Kaya, Bayram Ali (2007). Osman Nevres ve Dîvânı. İstanbul: Gökkubbe.

Levanoni, Amalia (2013). "A Supplementary Source for the Study of Mamluk Social History: The Taqârîz". Arabica 60. 146-177.

Muallim Naci (1986). Osmanlı Şairleri. Haz. Cemal Kurnaz, Ankara: Kültür ve Turizm Bakanlı̆̆ı Yayınları.

Muallim Naci (2009). Lügat-i Nâcî. Haz. Ahmet Kartal. Ankara: Türk Dil Kurumu Yayınları.

“Nergisî” (1987). Büyük Türk Klâsikleri 5. İstanbul: Ötüken Neşriyat.

Osmânzâde Hüseyin Vassâf (2006). Sefine-i Evliyâ. Haz. Mehmet Akkuş-Ali Yllmaz, İstanbul: Kitabevi.

Râmiz (1994). Râmiz ve Âdâb-ı Zürefâsı. Haz. Sadık Erdem. Ankara: Atatürk Kültür Merkezi Yayını. 
Rosenthal, Franz (1981). "Blurbs (Taqriz) From Fourteenth-Centruy Egypt". Oriens, 27/28.

177-196.

http:\{www.jstor.org/stable/1580566. [Erişim Tarihi: 11.12.2019]

Safâyî (2005). Tezkire-i Safâyî (Nuhbetü'l-Âsâr Min Fevâidi'l-Eş'âr). Haz. Pervin Çapan. Ankara: Atatürk Kültür Merkezi Yayını.

Sâlim (2005), Tezliretü'ş-şu'arâ. Haz. Adnan İnce. Ankara: Atatürk Kültür Merkezi Yayınları.

Şemseddin Sami (1317). Kâmûs-i Türkî. İstanbul: İkdam Matbaası.

Umaç, Zeynep Şimşek (2005). Birrî Mehmed Dede’nin Bülbüliye Adlı Eseri Üzerine Cümle Bilgisi İncelemesi Metin-Sözlük. Yüksek Lisans Tezi, Balıkesir: Balıkesir Üniversitesi.

Uzun, Mustafa-Ahmet Turan Arslan (2010). "Takriz", Türkiye Diyânet İslâm Ansiklopedisi, Cilt: 39, İstanbul. 472-474.

Vesely, Rudolf (2003). "Das Takriz in der arabischen Literatur", Die Memlûken -Studien zuihrer Geschichte und Kultur. Zum Gedenken an Ulrich Haarmann (1942-1999), Stephan Conermann-Anja Pistor-Hatam (Hg.). 379-385.

Woodhead, Christine (2000). "Puff and Patronaj: Ottoman takriz-writing and literary recommendation in the 17th century". The Balance of the truth. Essays in honour of Professor Geoffrey Lewis. Ed. Çiğdem Balım-Harding, C. Imber. İstanbul: Isis Press. 395-406.

Yavuz, Kemal. (2009). "Yusuf Has Hacib ve Kutadgu Bilig". İstanbul Üniversitesi Türk Dili ve Edebiyatı Dergisi, XXXVI.137-180.

Yûsuf Has Hâcib (2007). Kutadgu Bilig. Haz. Reşit Rahmeti Arat. Ankara: Türk Dil Kurumu Yayınları.

\section{Arşiv Kaynakları}

Birrî Mehmed Dede. Bülbüliyye. Süleymaniye Kütüphanesi Rauf Yekta. No: 77.

Birrî Mehmed Dede. Bülbüliyye. Süleymaniye Kütüphanesi İzmir No: 520

Fıtnat Hanım Divanı.Topkapı Sarayı Müzesi Kütüphanesi. No: H 921.

Nâbî Divânı. Millet Yazma Eser Kütüphanesi AEMNZ. No: 418.

Nâbî Divânı. Süleymaniye Kütüphanesi Hamidiye. No: 1118. 
Safâyı̂ Tezkiresi. Beyazıt Devlet Kütüphanesi Veliyüddin Efendi. No. 2585. Safâyî Tezkiresi. Millet Yazma Eser Kütüphanesi Thr. No: 771.

Şeyh Gâlib Divanı. Süleymaniye Kütüphanesi Halet Efendi. No: 658.

Seyyid Vehbî Divanı. Millet Yazma Eser Kütüphanesi AEMNZ. No: 497.

Takrîz ve Mekâtib. Süleymaniye Kütüphanesi Şehid Ali Paşa. No. 2831.

Takrizât. Süleymaniye Kütüphanesi Aşir Efendi. No. 417. 